\title{
Familial schizencephaly: further delineation of a rare disorder
}

\author{
F Haverkamp, K Zerres, B Ostertun, D Emons, M J Lentze
}

\begin{abstract}
We report on two Somalian sibs with severe developmental retardation and spastic cerebral paresis. Both children have bilateral cerebral clefts in the Sylvian region with dilatation of the ventricles, absence of the septum pellucidum, and heterotopia. The diagnosis of familial schizencephaly was made. The occurrence of schizencephaly in two affected sibs supports a genetic basis for schizencephaly.
\end{abstract}

( $\mathcal{F}$ Med Genet 1995;32:242-244)

Congenital clefts of the cerebral mantle are usually divided into encephaloclastic and schizencephalic porencephaly. ${ }^{1}$ When the porus is associated with a normally formed cortex, or the cortical lesions are observed secondary to a previously well formed cerebral mantle (for example, in combination with gliosis), this kind of porencephaly has been designated encephaloclastic porencephaly, which normally occurs in a late stage of gestation. ${ }^{12}$ In contrast schizencephaly can be defined as a defect in the cerebral mantle owing to a focal arrest of growth mainly located bilaterally along the primary cerebral fissures. ${ }^{1}$

Yakovlev and Wadsworth ${ }^{34}$ first presented extended histopathological descriptions of schizencephaly. They differentiated schizencephalic clefts with fused lips and with open lips (often associated with absence of the corpus callosum/septum pellucidum). Both conditions represent variable cerebral mantle defects of full thickness. ${ }^{5}$ According to Byrd et $a l^{t}$ the abnormality in schizencephaly is a pialependymal seam, a cleft lined with grey matter which extends across the full thickness of the cerebral hemispheres from the ventricular surface (ependyma) to the periphery (pial surface) of the brain. The aberrant neocortex (for example, micropachygyria, heterotopia) covering the "lips" of the lesion originates from a very

Received 16 August 1994 Revised version accepted fo publication 28 October 1994

Institut für Radiologie der Universität Bonn,

Correspondence to:

Familial schizencephaly

\begin{tabular}{|c|c|c|c|c|c|c|c|c|}
\hline \multirow[b]{2}{*}{$\begin{array}{l}\text { Sex } \\
\text { Familial relationship }\end{array}$} & \multicolumn{2}{|c|}{ Robinson $^{12}$} & \multicolumn{2}{|c|}{$\begin{array}{l}\text { Hosley } \\
\text { et } \text { al }^{13}\end{array}$} & \multicolumn{2}{|c|}{$\begin{array}{l}\text { Hillburger } \\
\text { et al }{ }^{l^{4}}\end{array}$} & \multicolumn{2}{|c|}{ This report } \\
\hline & $\begin{array}{l}\mathrm{F} \\
\text { Sibs }\end{array}$ & $\mathbf{M}$ & $\begin{array}{l}\mathrm{F} \\
\text { Half }\end{array}$ & $\begin{array}{l}M \\
\mathrm{bs}\end{array}$ & $\begin{array}{l}\mathrm{F} \\
\text { Sibs }\end{array}$ & F & $\begin{array}{l}\text { F } \\
\text { Sibs }\end{array}$ & $M$ \\
\hline Bilateral lips & + & + & - & + & - & - & + & + \\
\hline Unilateral lips & - & - & + & - & + & + & - & - \\
\hline Absence of pellucidum & - & - & + & + & - & - & + & + \\
\hline Heterotopia & - & - & + & + & - & - & + & + \\
\hline Gyral malformation & - & - & - & - & + & + & + & - \\
\hline Cerebral paresis & + & + & HP & + & HP & $\mathrm{HP}$ & + & HP \\
\hline Mental retardation & $(+)$ & $(+)$ & - & $(+)$ & + & + & + & $(+)$ \\
\hline Epilepsy & + & + & + & + & - & - & + & - \\
\hline
\end{tabular}

$+=$ marked,$(+)=$ moderate, $\mathrm{HP}=$ hemiparesis. early stage of gestation. ${ }^{15}$ Therefore schizencephaly is most likely the result of a neuronal migration failure and occurs during the earlier gestational period.

To differentiate encephaloclastic porencephaly from schizencephaly the presence or absence of aberrant neocortex and cerebral gliosis (glial scarring) is important. ${ }^{7}$ In schizencephaly no glial scarring is found. ${ }^{5}$ Schizencephaly is a very rare malformation and the aetiology is still unknown. Vascular disturbances, maternal trauma, fetal cytomegalovirus infection, or prenatal exposure to drugs (for example, cocaine) have been discussed. $^{8-11}$

There are a few familial cases of schizencephaly, which point to a genetic influence of the disease (table). We report on two severely handicapped children with schizencephaly from a Somalian family.

\section{Case reports}

CASE 1

The 8 year old daughter of unrelated Somalian parents was the product of an uncomplicated pregnancy. Both parents and further three sibs (two girls, one boy) are healthy. One younger brother is similarly affected (case 2). The extended family history showed no other affected relative. Height, weight, and head circumference at birth were reported as normal. At the age of 6 months developmental retardation was first noticed. At the age of 8 years the girl was brought to our hospital for investigation of severe psychomotor retardation and a predominantly left sided spasticity. She was unable to speak and had severe feeding difficulties. Clinical examination showed severe tetraspasticity and contractures of the large joints (elbow, hip, knee). Laboratory screening for metabolic diseases (for example, peroxisomal disorders, leucodystrophies, amino- and organic aciduria) and for infectious diseases was normal. Chromosomal analysis showed a normal female karyotype $(46, X X)$. Ophthalmological examination was unremarkable. The EEG showed a constant temporal theta rhythm.

Cerebral MRI (fig 1) showed bilateral schizencephalic clefts (open lips with heterotopia) in the typical location of the Sylvian fissure and absence of the septum pellucidum. The optic nerves were normal and there was no glial scarring.

CASE 2

The 4 year old younger brother of case 1 had a moderate congenital spastic right sided 


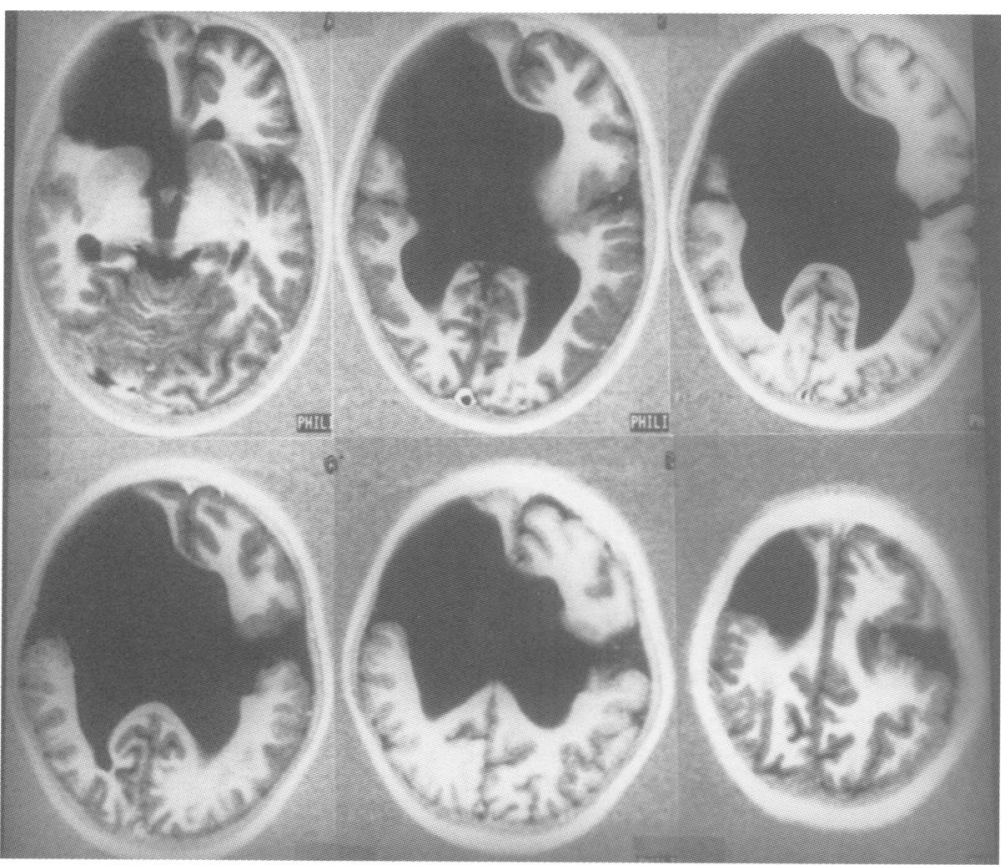

Figure 1 Bilateral schizencephalic clefts (open lips with heterotopia) in typical location of the Sylvian fissure. Absence of septum pellucidum. Optic nerves were normal and there was no gliosis. hemiparesis. Again, pregnancy, birth, and the neonatal period were uneventful. $\mathrm{He}$ was able to walk without support, used some words, and had no feeding problems. As in case 1 laboratory investigations were normal. The EEG records showed mild theta rhythms over the temporo-occipital regions. Ophthalmological and audiometrical findings were normal.

Cerebral MRI (fig 2) showed bilateral schizencephalic clefts in the typical location (Sylvian fissure). In the left hemisphere there was an open lip with heterotopia and irregular gyration of the schizencephalic cleft. The right hemisphere had a fused lip with heterotopia. There was absence of the septum pellucidum. The

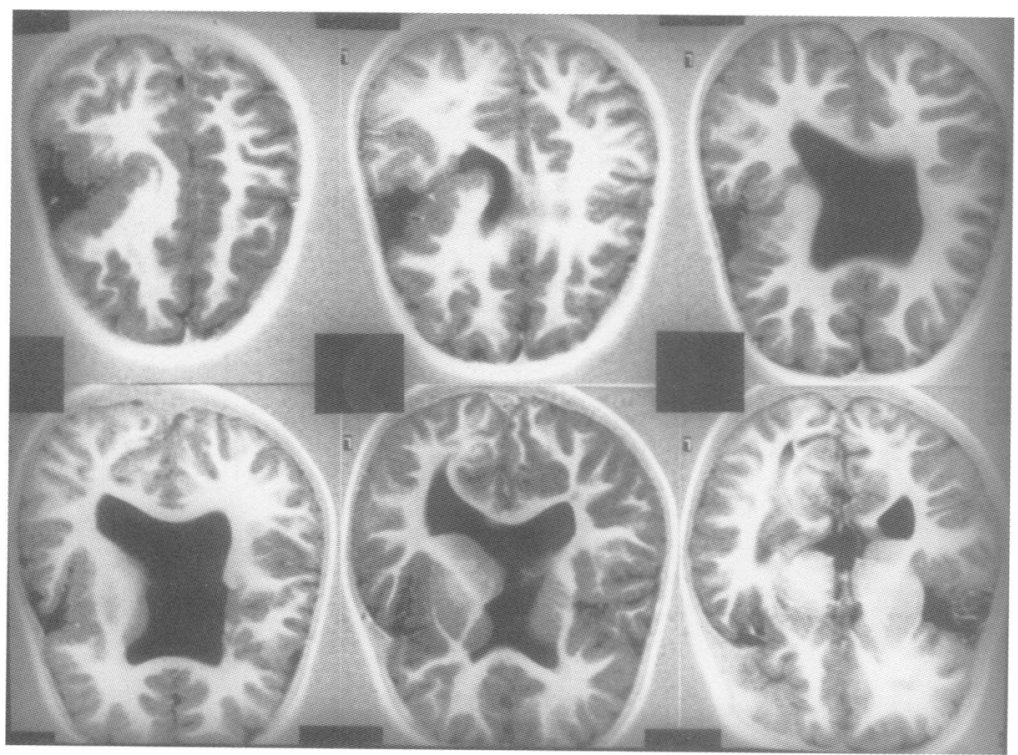

Figure 2 Bilateral schizencephalic clefts (left hemisphere: open lip with heterotopia and irregular gyration of the cortical rim of the schizencephalic cleft; right hemisphere: fused lip with heterotopia) in typical location (Sylvian fissure). Absence of septum pellucidum. Optic nerves were normal and there was no gliosis. optic nerves were normal and there was no glial scarring.

\section{Discussion}

With the exception of the extent of cerebral involvement, the neurological anatomy of both sibs is comparable. They both showed a bilateral porus with separated (and in case 2 fused) lips in the region of the Sylvian fissure, absence of the septum pellucidum, and heterotopias. Because of the typical bilateral localisation of the defect (Sylvan fissure) and additional features (heterotopia, absence of the septum pellucidum/corpus callosum) the diagnosis of familial schizencephaly was made. The different neuroanatomical extent of the schizencephalic clefts in both sibs corresponds to the patients' different degree of mental retardation and spastic paraparesis. Both affected sibs therefore seem to represent a different degree of expression of the same disorder. The simultaneous existence of an open and fused lip in case 2 shows that the differentiation in schizencephaly subtype I and subtype II according to Yakovlev and Wadsworth ${ }^{34}$ is more descriptive than representative of a different aetiology. The cerebral MRI of the mother was normal. Unfortunately the father could not undergo MRI because he was in Somalia. However, the clinical examination and mental status of the father were completely normal.

Familial schizencephaly is a rare disorder and few reports exist (table). In the reported cases all patients were unrelated, and no further affected family members have been reported. The patients described by Hosley et al ${ }^{13}$ were half sibs of different sex (same mother).

As with familial schizencephaly, cases with familial porencephaly have been reported by several authors and autosomal dominant inheritance with incomplete penetrance and variable expression has been postulated. ${ }^{15-20}$ Whether patients with familial schizencephaly can be differentiated from patients with familial porencephaly is questionable. So far in familial porencephaly only cerebral CT scanning has been used, a method which is known to be inferior to cerebral MRI scanning in detecting discrete lesions of neuronal migration disorders and the absence or presence of glial scarring. ${ }^{5}$ Furthermore the presence of unilateral findings (very frequent in familial porencephaly) do not exclude schizencephaly. The reports of Robinson $^{12}$ and Hilburger et $a l^{14}$ and our own observation are compatible with autosomal recessive inheritance, but half sibs as in the report of Hosley et al $^{13}$ raise the question of maternal (non-genetic) factors or autosomal dominant inheritance with incomplete penetrance. Non-genetic maternal factors as an explanation in affected sibs seem to be extremely unlikely.

$\mathrm{Up}$ to now the genetic basis remains unclear. However, because of the typical bilateral involvement in schizencephaly a genetic basis seems likely. In this context the observation of Barkovich and Kjos ${ }^{21}$ should be mentioned; they found contralateral isolated cortical dysplasia in unilateral schizencephaly, which 
underlines the bilateral involvement in schizencephaly. Therefore they proposed that schizencephaly is at one end of a spectrum ranging from focal cortical dysplasia to schizencephaly. For this reason high solution MR imaging in parents of patients with schizencephaly has been recommended to exclude schizencephaly or discrete cerebral lesions.

1 Raybaud C. Destructive lesions of the brain. Neuroradiology 1983;25:265-91.

2 Friede RL. Developmental neuropathology. 2nd ed. Berlin: Springer-Verlag, 1989:28-30.

3 Yakovlev PI, Wadsworth RC. Schizencephalies: a study of the congenital clefts in the cerebral mantle. II. Clefts with fused lips. F Neuropathol Exp Neurol 1946;5:116-30.

4 Yakovlev PI, Wadsworth RC. Schizencephalies: a study of the congenital clefts in the cerebral mantle. II. Clefts with hydrocephalus and lips separated. $\mathcal{F}$ Neuropathol Exp Neurol 1946;5:169-206.

5 Barth PG. Schizencephaly and nonlissencephalic cortical dysplasias. AfNR 1992;13:104-6.

6 Byrd SE, Osborn RE, Bohan TP, Naidich TP. The CT and MR evaluation of migrational disorders of the brain. Part II. Schizencephaly, heterotopia and polymicrogyria. $P$ diatr Radiol 1989;19:219-22.

7 Squier M, Keeling JW. The incidence of prenatal injury. Neuropathol Appl Neurobiol 1991;17:29-38.

8 Levine DN, Fisher MA, Caviness VS. Porencephaly with microgyria: a pathologic study. Acta Neuropathol (Berl) 1974;29:99-113.

9 Lyon G, Robain O. Etude comparative des encephalopathies circulatoires prenatales et paranatales. Acta Neumpathol (Berl) 1967;9:79-98.

10 Friede RL, Mikolasek J. Postencephalitic porencephaly, hydranencephaly or polymicrogyria. A review. Acta Neurohathol (Berl) 1978;43:161-8.

11 Dominguez R, Aguirre Vila-Coro A, Slopis JM, Bohan TP. Brain and ocular abnormalities in infants with in utero exposure to cocaine and other street drugs. Am $\mathcal{f}$ Dis Child exposure to cocaine and other street drugs. Am $F$ Dis Child

12 Robinson RO. Familial schizencephaly. Dev Med Child

Neurol 1991;33:1010-14.
13 Hosley MA, Abroms IF, Ragland RL. Schizencephaly: case report of familial incidence. Pediatr Neurol 1992;8:148-50.

14 Hilburger AC, Willis JK, Bouldin E, Henderson-Tilton A. Familial schizencephaly. Brain Dev 1993;15:234-6.

15 Berg RA, Kryiekos AA, Kaplan AM. Familial porencephaly. Arch Neurol 1983;40:567-9.

16 Airaksinen EM. Familial porencephaly. Clin Genet 1984;26: 236-8.

17 Smit LME, Bart PG, Valk J, Njiokiktiien C. Familial porencephalic white matter disease in two generations. Brain Dev 1984;6:54-8.

18 Sensi A, Cerruti S, Calzolari E, Vesce F. Familial porencephaly. Clin Genet 1990;38:396-7.

19 Zonana J, Adornato BT, Glass ST, Webb MJ. Familial porencephaly and congenital hemiplegia. $\mathcal{F}$ Pediatr 1986; 73:671-4.

20 Holmberg E, Holmgren G, v Zweigbergk M. Familial occurrence of porencephaly in two Swedish families. 8th currence of porencephaly in two Swedish famil
International Congress of Human Genetics, 1991.

21 Barkovich AJ, Kjos BO. Schizencephaly: correlations of clinical findings with MR characteristics. AfNR 1992;13: clinical 